\title{
Current Controlled PWM for Multilevel Voltage-Source Inverters with Variable and Constant Switching Frequency Regulation Techniques: A Review
}

\author{
S. P. Gawande ${ }^{\dagger}$ and M. R. Ramteke* \\ ${ }^{\dagger *}$ Department of Electrical Engineering, Visvesvaraya National Institute of Technology, Nagpur, India
}

\begin{abstract}
Due to advancements in power electronics and inverter topologies, the current controlled multilevel voltage-source pulse width modulated (PWM) inverter is usually preferred for accurate control, quick response and high dynamic performance. A multilevel topology approach is found to be best suited for overcoming many problems arising from the use of high power converters. This paper presents a comprehensive review and comparative study of several current control (CC) techniques for multilevel inverters with a special emphasis on various approaches of the hysteresis current controller. Since the hysteresis CC technique poses a problem of variable switching frequency, a ramp-comparator controller and a predictive controller to attain constant switching frequency are described along with its quantitative comparison. Furthermore, various methods have been reviewed to achieve hysteresis current control PWM with constant switching frequency operation. This paper complies various guidelines to choose a particular method suitable for application at a given power level, switching frequency and dynamic response.
\end{abstract}

Keywords: Hysteresis current control, Multilevel inverter, Pulse width modulation, Switching frequency

\section{INTRODUCTION}

Current controlled pulse width modulated (PWM) inverters are much more popular because of their good dynamic response. Since most of the applications for voltage-source pulse width modulated (PWM) inverters have a control structure involving an internal current feedback loop, their performance depends on the quality of the applied current control technique. As a result, the current control techniques for PWM voltage source inverters is one of the major area of research in modern power electronics. When compared with conventional open-loop PWM voltage source inverters (VSI),current-controlled PWM inverters have the advantages of extremely good dynamics, overload rejection, peak current protection, control of the instantaneous current waveforms, high accuracy, compensation of effects due to load parameter changes, compensation of the semiconductor voltage drops

Manuscript received Feb. 4, 2013; accepted Nov. 20, 2013

Recommended for publication by Associate Editor Rae-Young Kim.

${ }^{\dagger}$ CorrespondingAuthor:spgawande_18@yahoo.com

Tel: +91-7104-237919,Fax: +91-7104-232376,V.N.I.T

*Dept. of Electrical Eng., Visvesvaraya National Institute of Technology, India and dead time of the converters, compensation of the dc-link and ac-side voltage changes, etc.[1]. At present, thorough research is underway on the optimization of modulation techniques for multilevel inverters [2]. The fundamental block diagram of a voltage source inverter with PWM current control is shown in Fig 1. By comparing the load currents with the reference, the current controller generates switching states for the converters, to provide desired load current waveform by reducing the error of a load. Hence, in general, current controllers perform two difference tasks i.e. error compensation and modulation. The modulation process controls the phase switching sequence according to a given command, so that the phase voltage low order harmonics result in an average voltage over modulation period. Modulation also produces an instantaneous deviation of the current from its average value as an effect of voltage harmonics. The deviation amplitude depends on the duration of the modulation period, the supply voltage, the ac side average voltage and the load parameters [3]. With reference to the basic requirements, the accuracy of the current controller is evaluated. Some important requirements of the current controller includes low harmonic contents, good dc link voltage utilization, no phase and amplitude errors, and a 


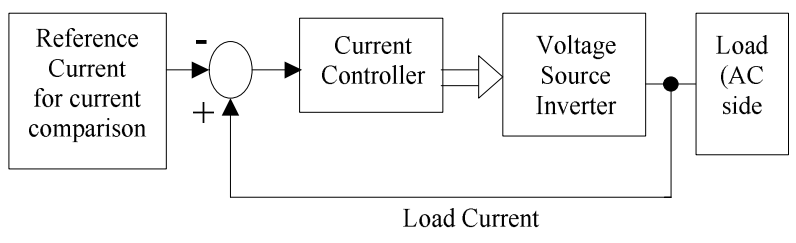

Fig. 1.Basic block diagram of current controller for VSI.

limited or constant switching frequency for safe operation of the switching power devices[1], [2]. The evaluation of the current controller may be done according to the performance criteria which include the static and dynamic performance. For some applications with specific needs like active filters, which require a very fast response or high power inverters, where the commutation must be minimized; the most suitable current control technique must be selected. In the following sections, the proposed current regulation techniques for two-level and multilevel inverters are explained using either linear or non-linear strategies with a variable and constant switching frequency.

\section{MultileVel Voltage Source INVERTER}

Various multilevel voltage source inverter topologies are proposed and effectively presented in the literature [4]-[7].Now a days, multilevel inverters are established topologies for use in higher power applications, since they are able to meet the high voltage and high power profiles with better harmonic spectrums at their outputs for a given switching frequency, with significantly reduced switching stresses, and without the need of higher rated power devices [8]. The single phase configuration of fundamental multilevel voltage source inverters i.e. three-level diode-clamped, four-level flying capacitor and five-level cascaded H-bridge topologies with a conventional two-level inverter are shown in Fig. 2. For a five-level inverter, $V_{A N}$ is given as, $V_{A N}=$ $n V_{d c}$, where $n=1 / 2,1 / 4,0,-1 / 4$, and $-1 / 2$, since a five-level inverter may select from within the range of voltage steps, $V_{d c} / 2, V_{d c} / 4,0,-V_{d c} / 4$ and $-V_{d c} / 2$ for the net dc-link voltage of $V_{d c}$ and corresponding to the higher voltage level inverters. The modulation of multilevel inverters using linear PWM controller strategies, are well reported [9] in the same way as the regulation of conventional two level inverters. Additionally, to generalize the already existing multilevel schemes, some modifications in the control approaches have been suggested.

\section{CURRENT CONTROLlERS FOR MULTILEVEL INVERTERS}

Several of the switching frequency based current controllers proposed in the literature are briefly reviewed in this section. The different current controlled strategies providing variable and constant switching frequencies for conventional two-level and multilevel voltage source inverters are classified as shown in Fig. 3.

\section{A. Variable Switching Frequency Control}

1)Hysteresis Current Control (HCC) Modulation Technique: The conventional hysteresis current control technique is very simple to implement. It has inherent peak current limiting capability, is used to determine the switching instants of each of the switching device and achieves a good dynamic response, an unconditional stability, and a wide command tracking bandwidth. The hysteresis controller has been found to be the most effective solution for all of the applications for current controlled voltage source inverters.

The purpose of a current controller is to control the load currents by forcing them to follow the reference currents. The hysteresis band (HB) specifies the maximum current deviation and thus, the inverter switching frequency will vary over a fundamental inverter period [3], [10], [11]. HCC is extensively used because of its simplicity. On the other hand, it has the limitations of a variable switching frequency and increased switching losses. In the literature, various approaches have been suggested to achieve a constant switching frequency under hysteresis control.

Based on the bands, two types of hysteresis current controllers have been suggested [12]. These include the fixed-band HCC and the sinusoidal-band HCC. In a sinusoidal band controller, the hysteresis band varies sinusoidally over a fundamental period, while in a fixed-band controller the band size is fixed.

2) HCC Modulation for Two Level Inverters: Several current control techniques for traditional inverters have been considered [1], [13], [14]. The purpose of two-level hysteresis current control is to switch the converter transistors in such a way that the converter load current tracks a reference within a specified hysteresis band.

The size of the hysteresis band is determined by the maximum permissible switching frequency of the switching devices used in the inverter and the highest permitted number of levels of current distortion [9]. A lower HB increases the switching losses and a larger $\mathrm{HB}$ results in increased distortion in the controlled current. Hence, the criteria for the selection of a hysteresis band size are crucial. Since only two dc levels are present, the two-level hysteresis control is very simple. However, for multilevel converters, since larger number of output voltage levels are present, it is essential to select a specific voltage-level output to force the control variable to zero on an instantaneous basis once it exceeds a certain bounding limit. Therefore, when a hysteresis controller is used for the modulation of a multilevel inverter it requires additional logic to select an appropriate voltage level 


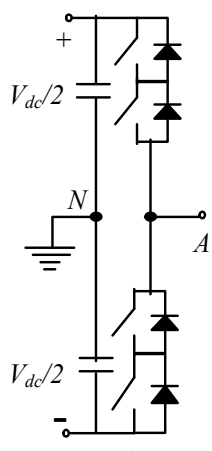

a)

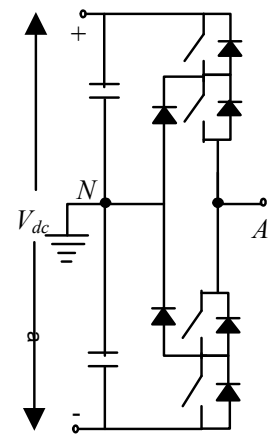

b)

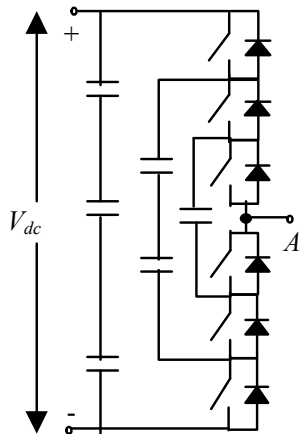

c)

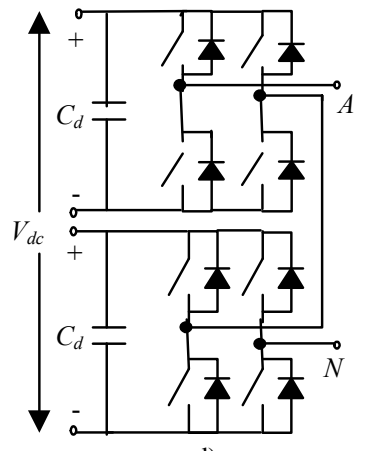

d)

Fig. 2. (a) Two-level.(b) Three-level diode clamped.(c) Four level flying capacitor.(d) Five-level cascaded H-bridge topologies.

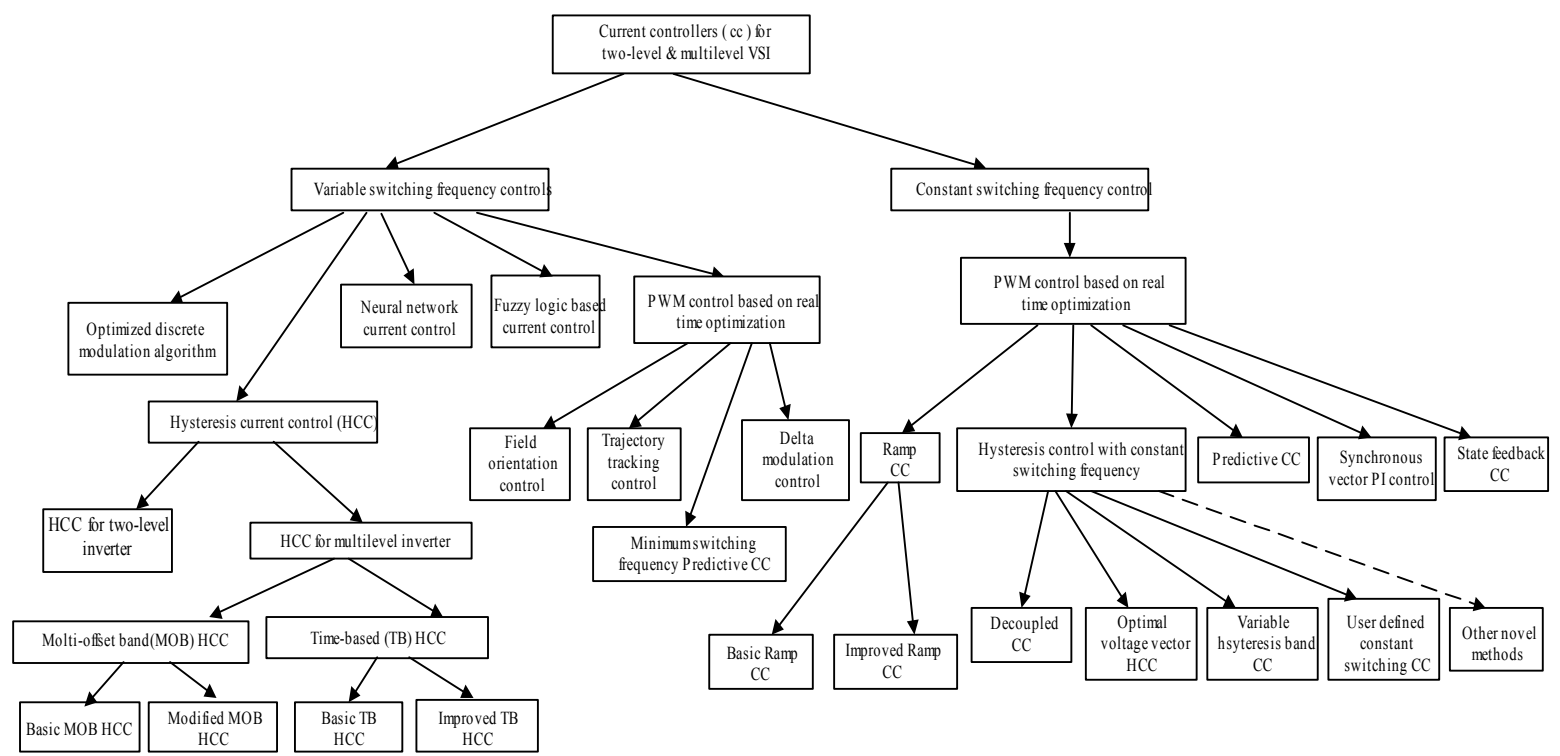

Fig. 3. Classification of current control techniques based on variable \& constant switching frequency regulation.
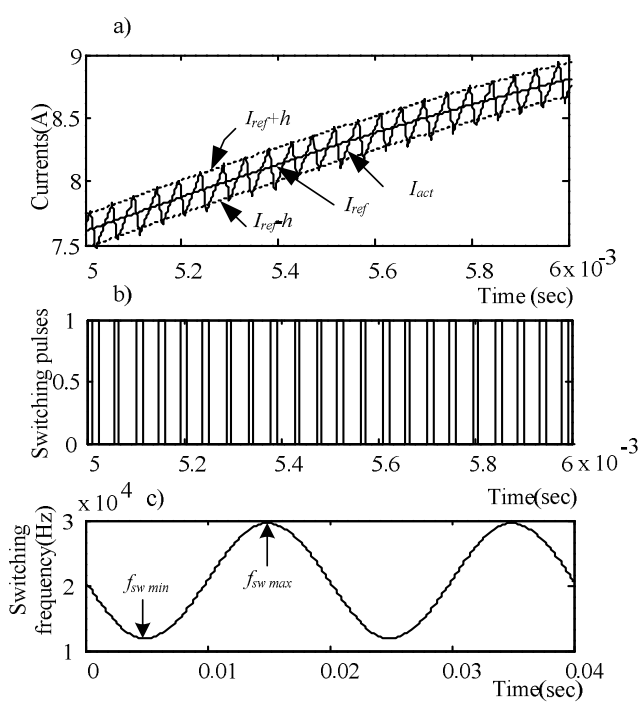

Fig. 4. Hysteresis PWM for 2-level VSI a) Switching dynamics b) Switching pulses c) Switching frequency variation. to keep the control signal within a specified HB.Fig. 4 shows the simulated results for a conventional 2-level inverter, using basic HCC. It consists of switching dynamics, switching pulse generation and variations in the switching frequency.

3) Multilevel HCC Modulation: The extension of the two-level hysteresis control algorithm to multi-level inverters [15], [16] is based on defining a set of $(n-1)$ hysteresis levels, where $n$ is the number of levels. representing the maximum allowable excursion of the actual current from the desired current as the hysteresis level $h_{(n-1)}$, the remaining $(n-1)$ hysteresis levels are computed as below and given by (1).

$$
h_{i}=\frac{i}{(n-1)} h_{(n-1)}
$$

Where $i=1,2,3,------,(n-1)$. 


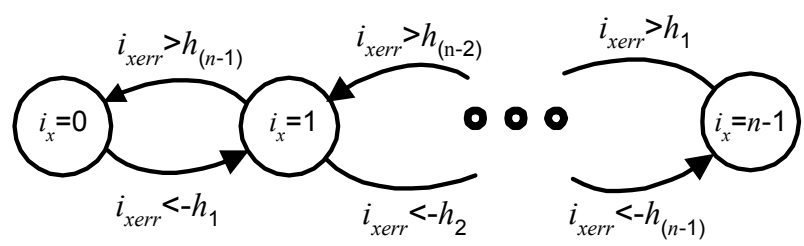

Fig. 5. Switching state diagram for $n$-level hysteresis regulation.

The switching of a particular phase $x$ is control by the phase current error $i_{\text {err }}$ represented by (2).

$$
i_{x e r r}=i_{x}^{*}-i_{x}
$$

Where $i_{x}$ and $i_{x} *$ are the actual and reference phase currents.

Similar to two-level hysteresis control, the general $n$-level switching state diagram for multilevel inverters is shown in Fig.5. It can be seen that smaller hysteresis switching cycles with slight current errors are possible. For systems where the current commands are dependent on the machine variables, such as field oriented controller [17], an additional control loop must be added to correct the error.

A possible technique that can be used to assist the current regulator in selecting the correct voltage level is the use of multiple hysteresis bands defined as multi-offset-band multilevel hysteresis current regulation (MOBMH) [9], [18]-[22]. For $n$ - level inverters, $(n-2)$ bands are required with each band representing the switching between two adjacent voltage levels. When a current error touches the corresponding bands, the fixed output voltage levels are switched. One major disadvantage of this technique is that the offset placements of the hysteresis bands about zero error introduce a steady state tracking error. As a result, an offset compensation strategy to ensure zero average current error within each switching period is required for improved performance. However, it requires complex analog circuitry.

A modified MOBMH [9] overcomes the above mentioned limitations of the MOBMH. In this technique, the current error needs to be bounded mainly between the two bands. To provide reliable and robust control of the inverter, an additional two offsets of the same width are placed out of bands. Hence, for n-level inverters ( $n$-2) offsets are required in both the positive and negative current error areas. In this scheme the switched voltage at the band crossing point of the current error is not fixed but depends on the previous voltage level which is just before the crossing point. If the current error crosses the positive boundary of a band with a positive slope, the next lower voltage level is switched and vice versa. The modified MOBMH is found to be more advantageous than the MOBMH in such a way that the current follows exactly the reference with a minimum change in the voltage.

The time-based multilevel hysteresis (TBMH) approaches proposed in [9], [20], [23], to control the current errors in three-level inverters, have an advantage since no dc-tracking error is introduced in the average output current. It was proposed that the current error could be controlled in a single band by selecting the output voltage levels one after the other. An outer hysteresis band was introduced optionally to allow for switching to extreme voltage levels for rapid current error detection during transient conditions. However, this logic is true only for three-level inverters and requires further modification for inverters beyond three-level. Therefore, an extra band is introduced, so that the voltage level transition becomes proper. Further, these bands increase as the number of levels increases. The size of the main band is determined by the permitted level of current distortion. The other factors which determine the band size are the load values, the input voltage and the desired switching frequency. It is obvious that this approach does not create any steady state tracking error of the multiple band scheme and also will require a very simple circuitry irrespective of the number of voltage levels. Although this technique, with some improvements, offers good performance, it needs to be further modified for better performance under all loading conditions and for very narrow hysteresis band sizes.

To overcome these drawbacks and to improve the performance of the TBMH scheme an efficient improved time-based approach (ITBMH) has been suggested [9]. This approach requires $(n-2)$ outer bands at the offset from their inner once for an $n$-level inverter. The current error slope detection based control suggested in [10] was replaced by an algorithm of the detection of only sign of the current error slope. The use of extra bands in the ITBMH indicates that if the current error is within the main band with a certain voltage switched at its boundary, the next voltage level will not be switched until the error touches outer band at the offset from the main band. Hence, it has been observed that the ITBMH replaces the combined monitoring of the vertical movement of the current error and the horizontal movement of the time, by only monitoring the vertical movement of the current error in deciding to switch the next voltage level out of the main band. The detailed performance of the ITBMH scheme is discussed in [23].

The simulation results for a 3-level NPC inverter, using the slope based current detection technique [10], which are shown in Fig. 6, clearly indicate that it also works satisfactorily for multilevel inverters. However, the drawback of variable switching frequency operation is still observed. Further, a comparison of the basic HCC scheme for the 2-level and slope based technique for 3-level NPC inverter, shown in Table I, indicates improved performance for the multilevel VSI.

4)PWM Controller Based On a Real Time Optimization Algorithm: A reduction in the switching frequency, as 

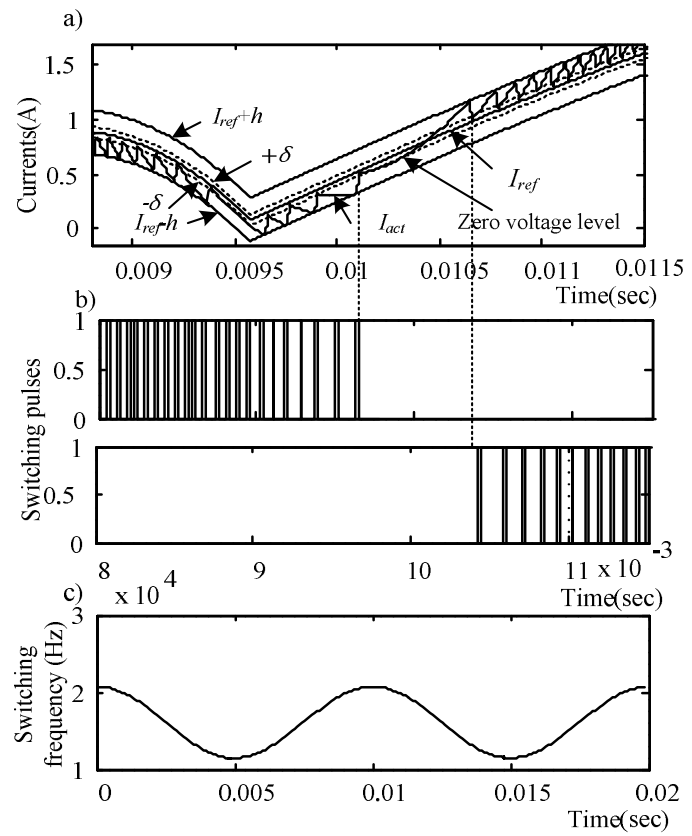

Fig. 6. Improved Hysteresis PWM for 3-level NPC VSI.(a) Switching dynamics.(b) Switching pulses.(c) Switching frequency variation.

TABLE I

COMPARISON OF HCC PWM FOR 2-LEVEL \& 3-LEVEL VSI

\begin{tabular}{|c|c|c|c|c|}
\hline \multirow[t]{2}{*}{ VSI } & \multirow[t]{2}{*}{$\operatorname{THD}(\%)$} & \multirow{2}{*}{$\begin{array}{l}\text { Number of } \\
\text { switching } \\
\text { (per cycle) }\end{array}$} & \multicolumn{2}{|c|}{$\begin{array}{c}\text { Switching frequency } \\
\left(f_{s w}\right) \text { in } \mathrm{kHz}\end{array}$} \\
\hline & & & $f_{s w \max }$ & $f_{\text {swmin }}$ \\
\hline 2-Level & 2.438 & 370 & 29.5 & 11.9 \\
\hline $\begin{array}{l}\text { 3-Level } \\
\text { (NPC) }\end{array}$ & 0.9135 & 230 & 21.7 & 11.8 \\
\hline
\end{tabular}

required in very high power applications, can be achieved by using the pulse width control with field orientation, by defining a current error boundary with a rectangular shape, and having the rectangle aligned with the rotor flux vector of the machine [2],[17],[24]. The selection of the switching state vectors is based on a prediction, satisfying the objective that the switching is minimized. Therefore, in some developed algorithms, a reduced set of voltage vectors consisting of the two active vectors adjacent to the EMF vector and the zero vectors are considered for optimization without a loss in terms of quality [25], [26].

Another effective approach proposed in [2], [27], [28] is the trajectory tracking control. It uses optimization to compensate for the dynamic tracking error of the converter currents. The control of off-line optimization for the steady-state and on-line optimization for transient operation exploits the advantages of both methods. With tracking control, the dynamic error is minimized and the optimal steady-state trajectory is reached immediately after the transient. The current space vector on the template trajectory constitutes a moving target, the location of which is determined by the actual phase angle of the voltage reference vector and by the fundamental current. In [61], [62], to attain accurate trajectory tracking a field oriented control combined with a linear controller is suggested.

The concept of a predictive algorithm based on a space-vector analysis of the hysteresis controllers [29] is the minimum switching frequency predictive current control. In this method, if only one hysteresis controller is used, the location of the error curve is determined by the current command vector. When the current vector reaches a point on the error curve, the different trajectories of the current are depicted, one for each of the possible inverter output voltage vectors. Finally, based on the optimization procedure, the voltage vector which minimizes the mean inverter switching frequency is selected.

The delta modulation method provides several advantages over the commonly used sine modulation process. A simple implementation of delta modulation in single-phase PWM inverters was first reported by [30]-[33].However, it does not theoretically investigate the modulation technique inverter performance. In this method, the encoded pulses are also locally decoded into analog signals by an integrator in the feedback loop and subtracted from the input signal to form an error signal. The closed loop arrangement of the delta modulator ensures that the polarity of the pulses is adjusted by the sign of the error signal. In the delta modulator, to obtain comparable results it should switch at a frequency about seven times higher than the PWM modulator. Further, a sensorless current mode (SCM) based delta modulator has been proposed [63] which can be used with any converter topology over a broad range of operating conditions.

5) Advanced Control Techniques: Based on the modulation strategies used for PWM based VSI, the controllers can be classified as linear and non-linear controllers. The linear controllers have clearly separate current error compensation and voltage modulation parts. The linear controllers operate with conventional voltage type PWM. Hence, they exploit the advantages of open-loop controllers like sinusoidal PWM, space-vector PWM and optimal PWM which are constant frequency controllers. These controllers include optimized discrete modulation algorithm, neural network and fuzzy logic based current controllers.

The optimal discrete current regulator algorithm is typically used for resonant DC link converters [34]-[36]. It chooses the nearest available voltage vector to the predicted desired voltage vector. This regulator minimizes the RMS current error. It was further proved that the RMS current error gets reduced to half that of the pulse density modulator.

The neural network $(\mathrm{NN})$ based current controller is a non-linear current controller based on this emerging technology. The main advantage of $\mathrm{NN}$ is the parallel processing, learning ability, robustness and generalization 
[37]-[40]. This control allows for the highest possible inverter switching frequencies. It has been proposed that NNs trained by observing line current errors are less complex and require less computation to train, while NNs trained by observing switched pattern errors are potentially more accurate. NNs can be implemented both with digital and hybrid, analog/digital circuitry. Finally NN based controllers can be used to regulate PWM inverter output current without the need for the on-line calculations required an optimal controller. Recently a NN based adaline algorithm has been proposed [64] which is able to control the voltage and frequency in an integrated manner.

A fuzzy logic (FL) based current controller is based on advanced technology and operates as a replacement for conventional PI controllers [41], [42], where the PI controllers are self-tuned by FL. The FL tuned PI controllers can be easily implemented for off-line operation. By using a FL current controller, the tracking error and transient overshoot of the PWM current control can be reduced to a greater extent. Further, the resulting performance of the controller depends on the design procedure. In [65] type-1 and type-2 FL controllers are suggested using the active-reactive control strategy. This is able to eliminate all of the uncertainties and shows the outstanding compensation abilities of a VSI. Further, FL with hysteresis control has been introduced [66] to improve the dynamic performance.

More recently, a combined NN and FL based technique called an adaptive neural-Fuzzy interface system (ANFIS) has been proposed [67]. The ANFIS has to be trained offline, while the data for the training obtained from measurements is based on the current model.

\section{B. Constant Switching Frequency Control}

1) Hysteresis Current Control witha Constant Switching Frequency: Various suggestions have been given and executed to overcome the problem of the variable switching frequency of hysteresis current controllers [43]-[45],[48]. These include minimizing the interference between the three phases by modifying the error feedback with a phase locked loop (PLL). It has been observed that these methods suffer from stability problems, transient performance limitations or complexity of implementation. In the case of large transients, the PLL may lose synchronization. However, a fast and accurate response in any case is ensured by the hysteresis control. Some of the novel methods proposed for constant switching frequency hysteresis control to overcome these limitations are: decoupled average constant switching frequency control, optimal voltage space vector based control, variable $\mathrm{HB}$ control and user defined constant switching frequency control.

HCC based on the optimum voltage space vectors is suggested as one of the simple method with a constant switching frequency [43]. In this method, the using trial and error method, two appropriate switches are selected based on the optimum voltage vector concept and are used to control two line to line currents independently with a constant switching frequency. In order to get the constant switching frequency, the dead band of hysteresis comparator must be variable taking into account the inverter phase voltage during the rising and falling intervals. The same idea can be further extended to three phases. Similar to the single phase basis, the constant switching frequency control of any two phases is independent [2].

Another very effective solution was given by [1], [44]. It was another type of adaptive hysteresis technique. It has a feature where the hysteresis window is automatically adjusted to maintain a constant switching frequency. Only the realized switching frequency differs slightly from the programmed value. It was concluded that this scheme operates satisfactorily at low switching frequencies. It achieves almost perfect regulation. In addition, the ripple frequency content is expanded in a narrow band instead of being concentrated in a single frequency peak. In this method the switching frequency becomes constant regardless the input and output voltage values.

The decoupled average constant switching frequency control approach eliminates the interference and its consequences [45].

A simple, novel method for a constant switching frequency for variable hysteresis band control for three phase inverters has been discussed [46]-[48]. It uses the open loop and closed loop technique to achieve a constant switching frequency. When the hysteresis band is fixed, the switching frequency varies. On the other hand, a desired constant switching frequency can be achieved successfully by calculating the proper value of the hysteresis band.

Further, a user defined constant switching frequency control has been suggested [49] for three phase three leg and four leg inverters. This scheme allows users to directly set the switching frequency. The proposed method ensures a constant and reduced switching frequency for all the switches of the inverter. This has been achieved by implementing an indirect control on the occurrence and the duration of the uncontrollable states (i.e. zero vector state). In the four leg VSI, three legs of the inverter are operated in hysteresis current tracking mode and the switches of the fourth leg are controlled to operate at a fixed user defined frequency. Its fast response makes this scheme attractive and it overcomes the major drawbacks of the conventional hysteresis controller.

Recently, a space-vector hysteresis current controller [68] has been proposed for 2-level VSI. In this method, the hysteresis boundaries are computed on line by using the stator voltage along the $\alpha$ and $\beta$-axes to achieve a constant switching frequency under steady state and transient conditions. This technique exhibits all the benefits of 
conventional hysteresis. Further, in [69] the same scheme is extended for $n$-level VSI to control variations in the switching frequency for the full linear modulation range.

Although the hysteresis controlled constant switching frequency schemes are more complex and the simplicity of the basic hysteresis control is lost, these solutions guaranteed a very fast response together with limited tracking errors. Thus, constant switching frequency hysteresis current control iswell suited for high performance, high speed applications.

\section{2) Ramp Comparator Current Controller and Modified} Ramp Comparator (MRC): A conventional ramp comparator is a conventional stationary linear controller, with a constant average switching frequency [3], [12]. The controller can be thought of as producing asynchronous sine-triangle PWM with the current error as a modulating function. If the current error is greater (less) than the triangular waveform, then the inverter leg is switched in the positive (negative) direction. The ramp controller can be implemented with or without hysteresis. Generally some hysteresis should be added to the controller to prevent multiple crossings of the error signals with the triangular wave. Since this controller uses the fixed frequency of a triangular carrier wave, the switching frequency of the inverter is kept constant, which is the main advantage of the controller. However, it suffers from some limitations like the output current amplitude and phase errors, load disconnection, etc., which are overcome in a modified ramp comparator [3], where phase shifters are included. In the modified ramp control the current error signals are compared with three $120^{\circ}$ phase shifted triangular waveforms having the same fixed frequency and amplitude. It was observed that there is no interaction between the operations of the three phases. As a result, the zero voltage vectors will be eliminated for balanced operation.

Fig. 7 depicts the performance of the modified ramp [3] with added hysteresis for constant and reduced switching frequency operation. The constant switching frequency PWM techniques viz. variable hysteresis band and modified ramp with hysteresis, for 3-level NPC inverters, are compared in Table II.

3) Predictive Current Controller: The constant inverter switching frequency predictive controller [50]-[53] calculates the inverter voltage vector, once every sample period. This forces the current to track the current command. The hybrid combination of predictive and hysteresis current control is also proposed in [16]. The predictive control is also known as the deadbeat control, when the choice of the voltage vector is made in order to null the error at the end of the sample period. Further, a predictive current controller with an extended state observer (ESO) has been suggested [70]. The proposed strategy calculates the converter switching time that
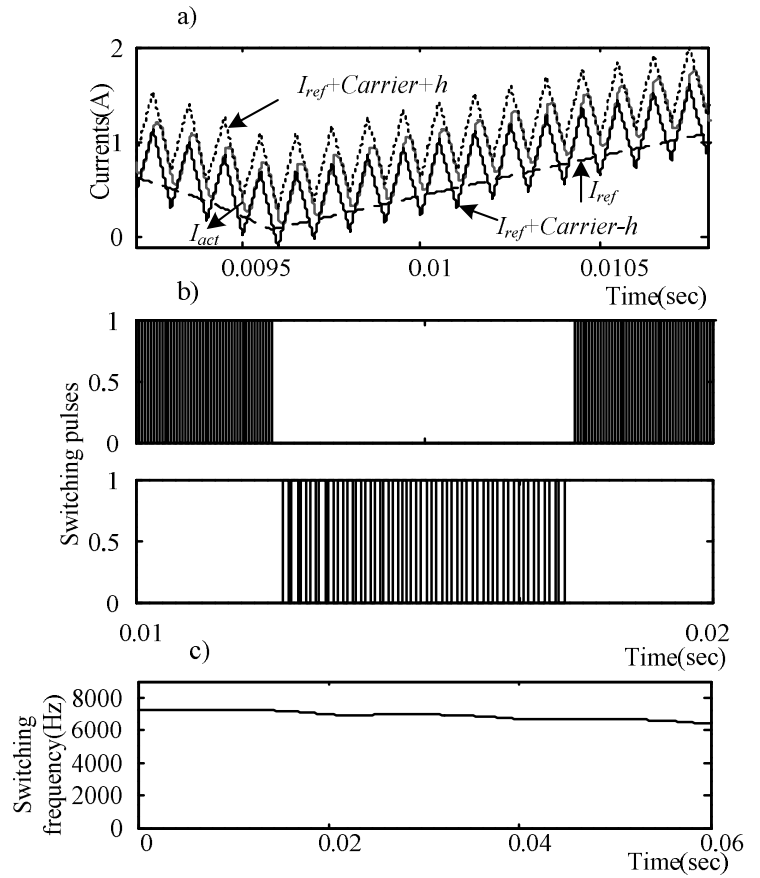

Fig. 7. Modified ramp with hysteresis PWM for 3-level NPC VSI.(a) Switching dynamics.(b) Switching pulses generation.(c) Constant switching frequency.

TABLE II

Constant Switching Frequency TeChNiques For 3-LeVEL VSI

\begin{tabular}{|c|c|c|c|}
\hline $\begin{array}{c}\text { Current } \\
\text { Control } \\
\text { Technique }\end{array}$ & THD(\%) & $\begin{array}{c}\text { Number of } \\
\text { switching } \\
\text { (per cycle) }\end{array}$ & $\begin{array}{c}\text { Switching } \\
\text { frequency } \\
(\mathrm{kHz})\end{array}$ \\
\hline $\begin{array}{c}\text { Variable } \\
\text { hysteresis } \\
\text { band }\end{array}$ & 0.9798 & 238 & 7.3 \\
\hline $\begin{array}{c}\text { Ramp with } \\
\text { hysteresis }\end{array}$ & 2.293 & 148 & 7.12 \\
\hline
\end{tabular}

minimizes the cost function, leading to a constant switching frequency.

\section{4) Other Constant Switching Frequency Linear}

Controllers: The other constant frequency controllers are the synchronous vector PI controller and the state feedback controller, where even small phase or amplitude errors cause incorrect system operation. Thus, it requires highly corrected currents. It consists of two current regulators generally defined in the rotating synchronous frame (dqo-axis) providing a constant switching frequency [54]-[56].

The state feedback is one of the linear current controllers, where the current regulators in the synchronous PI controller are replaced by a state feedback controller, which works in either the stationary [57] or synchronous rotating frames [58], [59]. The feedback gains can be derived by using the pole assignment approach. Since the control algorithm 

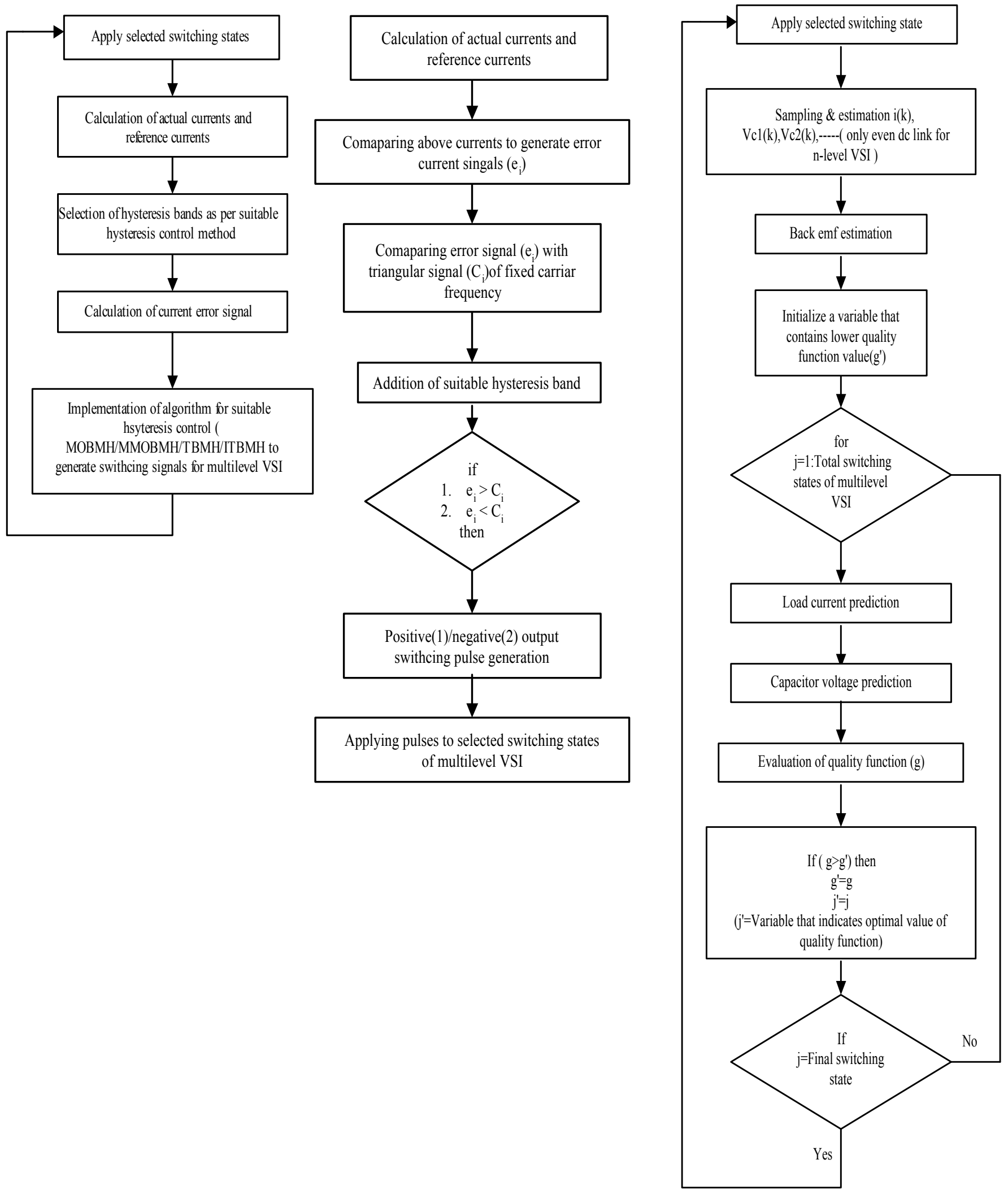

(a)

(b)

(c)

Fig. 8. Flow diagram of (a) Hysteresis current control (b) Ramp current control (c) Predictive current control for multilevel VSI control. 
TABLE III

Methodologies, Limitations, Advantages and Applications of Various CurRent Controlled PWM Methods

\begin{tabular}{|c|c|c|c|c|c|}
\hline $\begin{array}{l}\text { Sr. } \\
\text { No. }\end{array}$ & $\begin{array}{c}\text { Current Controlled } \\
\text { PWM Methods } \\
\text { [Reference Nos.] }\end{array}$ & Methodology/Control & Limitations & Benefits & $\begin{array}{c}\text { Typical } \\
\text { Applications }\end{array}$ \\
\hline 1 & $\begin{array}{l}\text { Basic Hysteresis } \\
\text { Current Control (HCC) } \\
\text { Modulation } \\
\quad[1]-[3],[8],[10]-[13]\end{array}$ & $\begin{array}{l}\text { Comparing reference } \\
\text { currents and load } \\
\text { currents with Hysteresis } \\
\text { band }(\mathrm{HB})\end{array}$ & $\begin{array}{l}\text { Variable Switching } \\
\text { Frequency (VSF), load } \\
\text { current contains } \\
\text { excess harmonics }\end{array}$ & Easy to implement & $\begin{array}{l}\text { Conventional } \\
\text { inverter based } \\
\text { drives \& high ac } \\
\text { power applications }\end{array}$ \\
\hline 2 & $\begin{array}{l}\text { Multi offset band } \\
\text { multilevel hysteresis } \\
(\text { MOBMH) } \\
\text { [9], [15], [18], [23] }\end{array}$ & $\begin{array}{l}\text { n-level inverter requires } \\
(n-1) \quad \mathrm{HB}, \quad \text { Switching } \\
\text { takes place when current } \\
\text { reverse the sign \& crosses } \\
\text { the boundary of band }\end{array}$ & $\begin{array}{l}\text { Skip some levels for } \\
\text { higher level inverter, } \\
\text { results in poor quality } \\
\text { inverter } \quad \text { output } \\
\text { voltage, generate } \\
\text { steady state trajectory } \\
\text { error, VSF. }\end{array}$ & $\begin{array}{l}\text { Robust as compared } \\
\text { to basic HCC }\end{array}$ & $\begin{array}{l}\text { Multilevel } \\
\text { inverters \& high ac } \\
\text { power applications }\end{array}$ \\
\hline 3 & $\begin{array}{c}\text { Modified MOBMH } \\
{[9],[23]}\end{array}$ & $\begin{array}{l}n \text {-level inverter requires } \\
(n-1) \text { offsets in both } \\
\text { positive \& negative } \\
\text { current error area }\end{array}$ & $\begin{array}{l}\text { Complex analog } \\
\text { circuitry, Variable } \\
\text { switching frequency }\end{array}$ & $\begin{array}{l}\text { Better inverter } \\
\text { voltage quality }\end{array}$ & $\begin{array}{l}\text { Multilevel } \\
\text { inverters \& high ac } \\
\text { power applications }\end{array}$ \\
\hline 4 & $\begin{array}{c}\text { Time based multilevel } \\
\text { hysteresis }(\mathrm{TBMH}) \\
{[9],[15],[18],[20],} \\
{[23]}\end{array}$ & $\begin{array}{l}\text { By controlling current } \\
\text { error in single band }\end{array}$ & $\begin{array}{l}\text { Satisfactorily works } \\
\text { only up to 3-level, lack } \\
\text { of robustness \& poor } \\
\text { transient response, } \\
\text { VSF }\end{array}$ & $\begin{array}{l}\text { Improved inverter } \\
\text { voltage quality }\end{array}$ & $\begin{array}{l}\text { Multilevel } \\
\text { inverters \& high ac } \\
\text { power applications }\end{array}$ \\
\hline 5 & $\begin{array}{l}\text { Improved TBMH } \\
\text { [9], [19], [22], [23] }\end{array}$ & $\begin{array}{l}\text { Requires }(n-2) \text { outer } \\
\text { bands with offsets for } \\
\text { n-level inverter }\end{array}$ & Heavy analog circuitry & $\begin{array}{l}\text { Improved } \\
\text { response, fast step } \\
\text { response, narrow } \\
\text { HB sizes }\end{array}$ & $\begin{array}{l}\text { Multilevel } \\
\text { inverters \& high ac } \\
\text { power applications }\end{array}$ \\
\hline 6 & $\begin{array}{l}\text { PWM with field } \\
\text { orientation } \\
\text { [2], [17], [24]-[26], } \\
\text { [61], [62] }\end{array}$ & $\begin{array}{l}\text { Using rectangular } \\
\text { boundary area in field } \\
\text { coordinates with reduced } \\
\text { switched frequency }\end{array}$ & $\begin{array}{l}\text { Time needed for } \\
\text { prediction } \quad \& \\
\text { optimization } \\
\text { procedure limits the } \\
\text { achieved switched } \\
\text { frequency }\end{array}$ & $\begin{array}{l}\text { Proper optimization } \\
\text { without loss of } \\
\text { quality }\end{array}$ & $\begin{array}{l}\text { High power } \\
\text { applications }\end{array}$ \\
\hline 7 & $\begin{array}{l}\text { Trajectory tracking } \\
\text { control } \\
{[2],[27],[28],[61],} \\
{[62]}\end{array}$ & $\begin{array}{l}\text { Continuous on-line } \& \\
\text { off-line optimization }\end{array}$ & $\begin{array}{l}\text { Unable to work for } \\
\text { very low switching } \\
\text { frequencies }\end{array}$ & $\begin{array}{l}\text { Good stationary \& } \\
\text { dynamic behavior }\end{array}$ & $\begin{array}{l}\text { High power } \\
\text { applications }\end{array}$ \\
\hline 8 & $\begin{array}{l}\text { Minimum switching } \\
\text { frequency predictive } \\
\text { algorithm[29] }\end{array}$ & $\begin{array}{lr}\text { Incorporate } & \text { predictive } \\
\text { algorithm based on } \\
\text { space-vector analysis } \\
\text { using optimization }\end{array}$ & $\begin{array}{l}\text { Complex } \\
\text { implementation }\end{array}$ & $\begin{array}{l}\text { Minimum response } \\
\text { time }\end{array}$ & $\begin{array}{l}\text { Medium power } \\
\text { applications }\end{array}$ \\
\hline 9 & $\begin{array}{l}\text { Delta modulation } \\
\text { current control } \\
{[21],[30]-[33],[63]}\end{array}$ & $\begin{array}{llr}\text { Analog signal are } \\
\text { encoded into pulses by } \\
\text { delta modulator } \& \\
\text { compared }\end{array}$ & $\begin{array}{l}\text { Ordinary delta } \\
\text { modulator has } \\
\text { tendency to drift in } \\
\text { time }\end{array}$ & $\begin{array}{l}\text { Insensitive to load } \\
\text { parameters, provides } \\
\text { constant } \mathrm{V} / \mathrm{F} \text { control } \\
\text { and smooth } \\
\text { transition to constant } \\
\text { voltage control } \\
\text { mode }\end{array}$ & $\begin{array}{l}\text { Static inverter } \\
\text { applications (UPS) }\end{array}$ \\
\hline
\end{tabular}




\begin{tabular}{|c|c|c|c|c|c|}
\hline 10 & $\begin{array}{c}\text { Optimized discrete } \\
\text { modulation algorithm } \\
{[34]-[36]}\end{array}$ & $\begin{array}{lcr}\text { Instead } & \text { of } & \text { PWM } \\
\text { algorithm } & \text { only voltage } \\
\text { vector selector is required }\end{array}$ & $\begin{array}{ll}\text { Less } & \text { switching } \\
\text { frequency } & \end{array}$ & $\begin{array}{ll}\text { Reduced } & \text { RMS } \\
\text { current error } & \end{array}$ & $\begin{array}{l}\text { Resonant } \\
\text { converters }\end{array}$ \\
\hline 11 & $\begin{array}{c}\text { Neural network (NN) } \\
\text { based current controller } \\
{[37]-[40],[64],[67]}\end{array}$ & $\begin{array}{l}\mathrm{NN} \text { trained by using line } \\
\text { current error } \& \text { switched } \\
\text { pattern error }\end{array}$ & $\begin{array}{l}\text { Implementation is } \\
\text { complex for complex } \\
\text { system }\end{array}$ & $\begin{array}{l}\text { Fast processing } \\
\text { speed and fault } \\
\text { tolerance, reduced } \\
\text { switching losses }\end{array}$ & $\begin{array}{l}\text { Power converters } \\
\text { in } \\
\text { applications }\end{array}$ \\
\hline 12 & $\begin{array}{l}\text { Fuzzy logic (FL) based } \\
\text { current controller } \\
{[41]-[42],[65]-[67]}\end{array}$ & $\begin{array}{l}\text { Tuning PI controller by } \\
\text { FL }\end{array}$ & $\begin{array}{l}\text { FL tuned PI } \\
\text { controllers are very } \\
\text { sensitive to any } \\
\text { change of fuzzy set }\end{array}$ & $\begin{array}{l}\text { Optimal tuning can } \\
\text { be achieved }\end{array}$ & $\begin{array}{l}\text { Control of power } \\
\text { converters }\end{array}$ \\
\hline 13 & $\begin{array}{l}\begin{array}{l}\text { Decoupled } \\
\text { switching } \\
\text { control } \\
\multicolumn{1}{c}{[45]} \\
\text { frequency }\end{array} \\
\end{array}$ & $\begin{array}{l}\text { Decoupling of error } \\
\text { signal by comparing } \\
\text { mean inverter voltage } \\
\text { with interference signal }\end{array}$ & $\begin{array}{l}\text { Control circuit is } \\
\text { bulky }\end{array}$ & $\begin{array}{l}\text { Constant switching } \\
\text { frequency }(\mathrm{CSF})\end{array}$ & $\begin{array}{l}\text { High power } \\
\text { applications }\end{array}$ \\
\hline 14 & $\begin{array}{c}\text { Optimal voltage space } \\
\text { vector based controller } \\
{[43],[68],[69]}\end{array}$ & $\begin{array}{l}\text { Using trail \& error } \\
\text { method location region of } \\
\text { reference voltage vector } \\
\text { is detected }\end{array}$ & Complex Modeling & $\begin{array}{lr}\text { CSF \& no need to } \\
\text { estimate } & \text { system } \\
\text { parameters } & \end{array}$ & $\begin{array}{l}\text { High power } \\
\text { applications }\end{array}$ \\
\hline 15 & $\begin{array}{l}\text { Adaptive hysteresis } \\
\text { technique } \\
\text { [44] }\end{array}$ & $\begin{array}{l}\text { Hysteresis window is } \\
\text { automatically adjusted } \\
\text { cycle by cycle }\end{array}$ & $\begin{array}{lr}\text { During } & \text { severe } \\
\text { transients } \quad \text { switching } \\
\text { frequency vary from } \\
\text { programmed value }\end{array}$ & $\mathrm{CSF}$ & $\begin{array}{lr}\text { Modern } & \text { High } \\
\text { performance } & \text { field } \\
\text { oriented AC } & \text { drive } \\
\text { control } & \\
\end{array}$ \\
\hline 16 & $\begin{array}{l}\text { Variable HB current } \\
\text { controller } \\
\text { [46]-[48], [68], [69] }\end{array}$ & $\begin{array}{l}\text { Use feedback \& feed } \\
\text { forward technique }\end{array}$ & $\begin{array}{l}\text { Variable HB control is } \\
\text { difficult }\end{array}$ & $\begin{array}{l}\text { CSF \& good } \\
\text { dynamic response }\end{array}$ & $\begin{array}{l}\text { Conventional } \\
\text { two-level, } \\
\text { multilevel VSI }\end{array}$ \\
\hline 17 & $\begin{array}{l}\text { User defined constant } \\
\text { switching (UDCS) } \\
\text { frequency controller } \\
{[49]}\end{array}$ & $\begin{array}{l}\text { Switches are controlled } \\
\text { with square wave pulse of } \\
\text { fixed frequency }\end{array}$ & More complex scheme & $\begin{array}{l}\text { CSF with robust, } \\
\text { simple \& } \begin{array}{r}\text { fast } \\
\text { response }\end{array}\end{array}$ & $\begin{array}{l}\text { High performance } \\
\& \text { high speed } \\
\text { applications }\end{array}$ \\
\hline 18 & $\begin{array}{lr}\text { Conventional } & \text { ramp } \\
\text { comparator } & \text { current } \\
\text { controller } & \\
{[3],[12]} & \end{array}$ & $\begin{array}{l}\text { Comparing current error } \\
\text { with triangular signal }\end{array}$ & $\begin{array}{l}\text { Output current has } \\
\text { amplitude \& phase } \\
\text { error results in } \\
\text { transmission delay in } \\
\text { the system }\end{array}$ & $\mathrm{CSF}$ & $\begin{array}{l}\text { High performance } \\
\& \\
\text { applications }\end{array}$ \\
\hline 19 & $\begin{array}{l}\text { Modified } \\
\text { comparator } \\
\text { controller } \\
{[3]}\end{array}$ & $\begin{array}{l}120^{0} \text { phase shifter is } \\
\text { included to compare error } \\
\text { signal }\end{array}$ & $\begin{array}{l}\text { Modeling algorithm is } \\
\text { complex }\end{array}$ & $\begin{array}{l}\text { CSF with } \\
\text { elimination of zero } \\
\text { voltage vectors }\end{array}$ & $\begin{array}{l}\text { Microprocessor, } \\
\text { microcontroller } \\
\text { based industrial } \\
\text { motor drive } \\
\text { applications with } \\
\text { CSF }\end{array}$ \\
\hline 20 & $\begin{array}{l}\text { Predictive current } \\
\text { controller } \\
{[1],[2],[50]-[53],[70]}\end{array}$ & $\begin{array}{l}\text { Calculate inverter voltage } \\
\text { vector once every sample } \\
\text { period }\end{array}$ & $\begin{array}{l}\text { Algorithm does not } \\
\text { guarantee the inverter } \\
\text { peak current limit }\end{array}$ & $\begin{array}{lrr}\text { CSF, does } & \text { not } \\
\text { require } & \text { linear } \\
\text { controller } & \end{array}$ & $\begin{array}{lr}\text { Advanced } & \text { DSP } \\
\text { based } & \text { Power } \\
\text { converters } & \& \\
\text { drives applications }\end{array}$ \\
\hline 21 & $\begin{array}{l}\text { Synchronous vector PI } \\
\text { controller } \\
{[54]-[58],[59]}\end{array}$ & Space-vector approach & $\begin{array}{l}\text { Performance is } \\
\text { inferior to bang-bang } \\
\text { controller }\end{array}$ & $\mathrm{CSF}$ & $\begin{array}{l}\text { Industrial } \\
\text { application such as } \\
\text { vector controlled } \\
\text { motors }\end{array}$ \\
\hline 22 & $\begin{array}{ll}\text { State } & \text { feedback } \\
\text { controller } & \\
{[1],[71],[72]} & \end{array}$ & $\begin{array}{l}\text { Current regulator are } \\
\text { replaced by state } \\
\text { feedback controllers } \\
\text { working in stationary or } \\
\text { rotating frame }\end{array}$ & $\begin{array}{l}\text { Performance is } \\
\text { inferior to bang-bang } \\
\text { controller }\end{array}$ & $\begin{array}{l}\text { CSF } \\
\text { performance } \\
\text { Superior } \\
\text { conventional } \\
\text { controller }\end{array}$ & $\begin{array}{l}\text { Industrial } \\
\text { application }\end{array}$ \\
\hline
\end{tabular}


gives dynamically correct compensation, the performance of the state feedback controller is superior to conventional PI controllers [60].To gain optimal capability in state feedback control, various optimization techniques can be apply like particle swarm optimization (PSO), genetic algorithm (GA), biogeography based optimization (BBO), etc. [71].Considering the stability issue arising in linear time invariant (LTI) systems, [72] investigates a stability analysis for LTI systems which is found to be suitable to preserve the closed loop performance of the system.

\section{DISCUSSION}

Flow-diagrams for the hysteresis, ramp and predictive current control schemes for multilevel voltage source inverters are shown in Fig. 8, while Table III summarizes the methodology/control, limitations, benefits and typical applications of various variable and constant switching frequency current controllers. It is evident from Table III that the performance of the system largely depends on the applied current control strategy. Since the current controlled PWM schemes have many advantages when compared to conventional PWM controllers, they are mostly preferred in many industrial applications. Linear controllers like the stationary PI controller, synchronous vector PI controller, state feedback controller, ramp controller predictive and deadbeat controller always exploit the benefits of open-loop controllers like the sinusoidal PWM, space vector PWM, etc. which are constant switching frequency controllers. Variable switching frequency controllers are non-linear controllers which include basic hysteresis and its modified techniques, delta modulation, optimized controllers, neural network based controllers, fuzzy logic tuned controllers, etc. The most common drawback of these non-linear current controllers is their inability to provide a constant switching frequency and the fact that they are generally very sensitive to load parameter variations. Some methods are not suitable for multilevel inverters with more than three levels. However, with slight modifications, a satisfactory response with a better power quality in the multilevel inverter output voltage can be achieved. An attempt has also been made by combining or modifying the control techniques of two or individuals to improve the response. Furthermore, it has been proposed to developed innovative current control PWM schemes for hybrid multilevel inverters, modular multilevel and some improved multilevel topologies.

In addition to this, in future, hysteresis and its improved versions like MMOBMH and ITBMH, which usually provide a variable switching frequency can be modified by using robust controls for achieving a constant switching frequency. The use of robust controls determines the control law and maintains the system response and error signals within prescribed tolerance despite uncertainty in the system. In addition, in the future self-organizing fuzzy logic control
(SOFLC) based optimization strategies can be used to modify the control techniques, which can be further extended to the predictive SOFLC, in order to track the changing dynamics of VSI applications. SOFLC can also be implemented in non-linear control PWMs by incorporating a genetic algorithm to adapt the membership function.

\section{CONCLUSIONS}

This paper presented a comprehensive review of the different current control PWM techniques used for conventional and multilevel voltage source inverters. The conventional current control modulation, its improved versions and recent techniques have been summarized. It has been seen that higher level VSIs require further modification in the control scheme and control algorithm of implemented technique. Controller classification on the basis of variable and constant switching frequency is shown. The basic principles, latest development and a quantitative comparison of these techniques have been systematically described. The benefits and limitations have been outlined, and the application field, where a particular method is suited has been described. Taking into consideration the problem of a variable switching frequency in case of hysteresis current controllers, which increases the switching losses, the various latest constant switching frequency techniques are discussed and recommended.

\section{REFERENCES}

[1] M. P. Kazmierkowski and L. Malesani, "Current control techniques for three- phase voltage-source PWM converters: A survey," IEEE Trans. Ind. Electron., Vol.45, No.5, pp. 691-703,Oct.1998.

[2] J.Holtz, "Pulse width modulation- A survey,"IEEE Trans. Ind. Electron.Vol.39, No.5, pp. 410-420,Dec. 1992.

[3] D.M.Brod and D.W.Novotny, "Current control of VSI-PWM inverters,” IEEE Trans. Ind. Appl., Vol. IA-21, No.3,pp. 562-570, May/June 1985.

[4] J.Rodriguez, J.-S. Lai, and F.Z.Peng, "Multilevel inverters: A survey of topologies, controls, and applications," IEEE Trans. Ind. Electron., Vol.49, No.4, pp. 724-738, Aug. 2002.

[5] G.Carrara, M.Marchesoni, R.Salutari, and G.Sciutto, "A new multilevel PWM method: A theoretical analysis," IEEE Trans. Power Electron.,Vol. 7, No. 3, pp. 497-505,Jul. 1992.

[6] J.-S.Lai and F.Z.Peng, "Multilevel converters- A new breed of power converters," IEEE Trans. Ind. Appl., Vol. 32, No. 3, pp.509-517, May/Jun. 1996.

[7] L.M.Tolbert, F.Z.Peng, and T.G.Habetler, "Multilevel converters for large electric drives," IEEE Trans. Ind. Appl., Vol. 35, No. 1, pp. 36-44 Jan./Feb. 1999.

[8] K.A.Corzine, "A hysteresis current-regulated control for multilevel drives," IEEE Trans. Energy Conv., Vol. 15, No. 2, pp. 169-175, Jun. 2000.

[9] A.Shukla, A.Ghosh, and A.Joshi, "Hysteresis modulation of multilevel inverters,"IEEE Trans. Power Electron.Vol. 26, No. 5, pp.1396-1409, May 2011

[10] A.B.Plunkett, "A current-controlled PWM transistor 
inverter drive," in Proc.IAS., pp.785-92, 1979.

[11] G.Pfaff, A.Weschta, and A.Wick, "Design and experimental results of a brushless ac servo-drive," in Proc. IAS, pp.692-97, 1979.

[12] M.A.Rahman, T.S.Radwan, A.M.Osheiba, and A.E.Lashine, "Analysis of current controllers for voltage-source inverter," IEEE Trans. Ind. Electron., Vol. 44, No. 4, pp.477-485, Aug. 1997.

[13] O.Kukrer, "Discrete-time current control of voltage-fed three-phase PWM inverters," IEEE Trans. Power Electron.Vol. 11,No. 2, pp. 260-269, Mar. 1996.

[14] A.V.Anunciada, "A new current mode control proses and applications," IEEE Trans. Power Electron.Vol. 6, No. 4 pp.601- 610, Oct. 1991 .

[15] F.Zare and G.Ledwich, "A hysteresis current control for single-phase multilevel voltage source inverters: PLD implementation," IEEE Trans. Power Electron.,Vol. 17, No. 5, pp. 731-738, Sep. 2002

[16] N.Mohan, T.M.Undeland, and W.P.Robbins, Power Electronics, Converters, Applications and Design, John Wiley \& Sons, New York, 1989.

[17] A.M.Trzynadlowski, "The field oriented principle in control of induction motor," Kluwer academic, 1994

[18] G.H.Bode and D.G.Holmes, "Implementation of three level hysteresis current control for single phase voltage source inverters,"in Proc.PESC, pp.33-38, 2000.

[19] G.H.Bode, D.N.Zmood, P.C.Loh, and D.G.Holmes, "A novel hysteresis current controller for multilevel single phase voltage source inverter," in Proc.PESC, pp.1845-1850, 2001.

[20] P.C.Loh, G.H.Bode, D.G.Holmes, and T.A.Lipo, "A time-based double band hysteresis current regulation strategy for single-phase multilevel inverters," IEEE Trans. Ind. Appl.,Vol. 39, No. 3, pp. 883-892, May/Jun. 2003.

[21] M.Marchesoni, "High performance current control techniques for applications to multilevel high power voltage source inverters," IEEE Trans. Power Electron.,Vol. 7, No. 1, pp.189-204, Jan. 1992.

[22] A.Shukla, A.Ghosh, and A.Joshi, "Hysteresis current control operation of flying capacitor multilevel inverter and its application in shunt compensation of distribution systems," IEEE Trans. Power Del., Vol. 22, No. 2, pp. 396-405, Jan. 2007.

[23] A.Shukla, A.Ghosh, and A.Joshi, "Improved multilevel hysteresis current regulation and capacitor voltage balancing schemes for flying capacitor multilevel inverter," IEEE Trans. Power Electron., Vol. 23, No. 1, pp. 518-529, Mar. 2008.

[24] M.P.Kazmierkowski and W.Sulkowski, "A novel vector control scheme for transistor PWM inverter-fed induction motor drive," IEEE Trans. Ind. Electron., Vol. 38,No. 1, pp. 41-47, Feb.1991.

[25] A.Khamadkone and J.Holtz, "Low switching frequency high-power inverter drive based in field-oriented pulse width modulation," in Proc. EPE., pp.4672-4677, 1991.

[26] J.Holtz and E.Bude, "Field oriented asynchronous pulse width modulation for high performance ac machine drive operating at low switching frequency," IEEE Trans. Ind. Appl., Vol. 27,No. 3, pp. 574-581, May/Jun. 1991.

[27] J.Holtz and B.Bayer, "Fast current trajectory tracking control based on synchronous optimal pulse width modulation," IEEETrans. Ind. Appl., Vol. 31,No. 5, pp.1110-1120, Sep./Oct. 1995.

[28] J.Holtz and B.Bayer, "The trajectory tracking approach-A new method for minimum distortion PWM in dynamic high power drive," IEEE Trans. Ind. Appl.,Vol. 30,No. 4, pp.1048-1057, July/Aug. 1994.

[29] J.Holtz and S.Stadtfeld, "A predictive controller for the state current vector of ac machine fed from a switch voltage source,"in Proc.IPEC, pp.1665-75, 1983.

[30] P.D.Zoigas, "The delta modulation technique in static PWM inverters," IEEE Trans. Ind. Appl.,Vol. IA-17, No. 2 pp.199-204, Mar./Apr. 1981.

[31] M.A.Rahman, J.E.Quaicoe, and M.A.Choudhary, "Performance analysis of delta modulated PWM inverters,"IEEE Trans. Power Electron. Vol. PE-2, No. 3, pp.227-233, Jul. 1987.

[32] M.Kheraluwala and D.M.Divan, "Delta modulation strategies for resonant dc link inverters,"in Proc. PESC,pp.271-278, 1987.

[33] R.D.Lorenz and D.M.Diwan, "Dynamic analysis and experimental evaluation of delta modulators for field oriented ac machine current regulators," in Proc.IAS, Annu. Meet., pp.196-201, 1987.

[34] G.Venkataramanan, D.M.Diwan, and T.M.Jahns, "Discrete pulse modulation strategies for high frequency inverter systems," in Proc. PESC, pp.1013-1020, 1989.

[35] S.K.Bul, B.H.Kwon, J.K.Kang, K.J.Lim, and M.H.Park, "Design of an optimal discrete current regulator,"in Proc. IAS, Annu. Meet., pp.348-354,1989.

[36] D.S.Oh, K.Y.Cho, and M.J.Youn, "A discretized current control technique with delayed voltage feedback for a voltage-fed PWM inverter,"IEEE Trans. Power Electron.,Vol. 17, No. 2,pp. 364-373, Apr. 1992.

[37] F.Harashima,Y.Demizu,S.Kondo, and H.Hashimoto,"Application of neural networks to power converter control,"in Proc.IAS,pp.1087-1091, 1989.

[38] M. R. Buhl and R.D.Lorenz, "Design and implementation of neural networks for digital current regulation of inverter drive,"inProc. IAS, pp.415-421,1991.

[39] B.Burton, R.G.Harley, G.Diana, and J.R.Rodgerson, "Implementation of a neural network to adaptively identify and control VSI fed induction motor stator currents," in Proc. IAS, pp.1733-1740, 1994.

[40] B.Burton, F.Kamran, R.G.Harley, T.G.Habetler, M.A.Brooke, and R.Poddar, "Identification and control of induction motor stator currents using fast on-line random training of a neural network," IEEE Trans. Ind. Appl., Vol. 33, No. 3,pp.697-704, May/Jun. 1997.

[41] M.A.Dzienialowski, and M.P.Kazmierkowski, "Self-tuned fuzzy PI current controller for PWM-VSI,"in Proc. EPE, pp.1308-1313, 1995.

[42] M.A.Dzieniakowski and P.Z.Grabowski, "Fuzzy logic controller with state recognition for three phase PWM-VSI," in Proc.ISIE, pp.438-443, 1996.

[43] L.Malesani and P.Tenti, "A novel hysteresis control method for current-controlled voltage-source PWM inverter with constant modulation frequency," IEEE Trans. Ind. Appl.,Vol. 26, No. 1,pp.88-92, Jan./Feb.1990.

[44] B.K.Bose, "An adaptive hysteresis-band current control technique of voltage-fed PWM inverter for machine drive system,"IEEE Trans. Ind. Electron., Vol. 37, No. 5,pp.402-408,Oct. 1990.

[45] L.Malesani, P.Tenti, E.Gaio, and R.Piovan, "Improved current control technique of VSI PWM inverters with constant modulation frequency and extended voltage range," IEEE Trans. Ind. Appl.,Vol. 27, No. 2,pp. 365-369.Mar./Apr. 1991.

[46] Q.Yao and D.G.Holmes, "A simple, novel method for variable-hysteresis band current control of a three phase 
inverter with constant switching frequency," in Proc. PESC., pp.986-992, 1993.

[47] F.Liu and A.I.Maswood, "A novel variable hysteresis band current control of three-phase three-level unity PF rectifier with constant switching frequency," IEEE Trans. Power Electron.,Vol. 26, No. 6, pp. 1727-1734, Nov. 2006.

[48] J.Zeng, C.Yu, and Q.Q1, "A novel hysteresis current control for active filter with constant frequency,"Electr. Power Syst.Res. Vol. 68, No. 1, pp.75-82, Jan. 2004.

[49] V.George and M.K.Mishra, "User-defined constant switching frequency current control strategy for a four-leg inverter," IET Power Electron., Vol. 2, No. 4, pp. 335-345, Jul. 2009.

[50] Z.Song, C.Xia, and T. Liu "Predictive current control of three-phase grid connected converters with constant switching frequency for wind energy systems," IEEE Trans. Ind. Appl. ,Vol. 60, No. 6, pp. 2451-2464,Oct. 2012

[51] R.Wu, S.B.Dewan, and G.R.Slemon, "Analysis of a PWM ac to dc voltage source converter under the predicted current control with a fixed switching frequency," IEEE Trans. Ind. Appl.,Vol. 27, No. 4,pp.756-764, Jul./Aug. 1991.

[52] L.Zhang and F.Hardan, "Vector controlled VSI-fed AC drive using a predictive space-vector current regulation scheme," in Proc. IECON., pp.61-66, 1994.

[53] R.Vargas, P.Cortes, U.Ammann, J.Rodriguez, and J.Pontt, "Predictive control of a three-phase neutral-point-clamped inverter,"IEEE Trans. Ind. Electron.,Vol. 54, No.5, pp.2697-2705, Oct. 2007.

[54] W.Leonhard, Control of Electrical Drives,2nd Ed., Springer-Verleg, Germany, 1996.

[55] C.T.Rim, N.S.Choi, G.C.Cho, and G.H.Cho, "A complete $\mathrm{DC}$ and $\mathrm{AC}$ analysis of three-phase controlled-current PWM rectifier using circuit D-Q transformation," IEEE Trans. Power Electron.,Vol. 9, No. 4, pp. 390-396, Jul. 1994.

[56] R.B.Sepe and J.H.Lang, "Inverter non-linearities and discrete-time vector current control, "IEEE Trans. Ind. Appl.,Vol. 30. No. 1, pp.62-70, Jan./Feb. 1994.

[57] R.D.Lorenz and D.B.Lawson, "Performance of feed-forward current regulators for field oriented induction machine controllers," IEEE Trans. Ind. Appl., Vol. IA-23, No. 4, pp. 597-602, Jul. 1987.

[58] J.Moerschel, "Signal processor based field oriented vector control for an induction motor drive,"in Proc. EPE,pp.2145-2150, 1991.

[59] C.Andrievx and M.J.Mazenc, "Analysis of different current control systems for inverter fed synchronous machine,"in Proc. EPE, pp.2159-2165, 1985.

[60] P.Feller, "Speed control of an ac motor by state variables feedback with decoupling," in Proc.IFAC, pp.87-93, 1983.

[61] H. Sira-Ramirez, F. Gonzalez-Montanez, J. A. Cortes-Romero, and A. Luviano-Juarez, "A robust linear field-oriented voltage control for the induction motor: experimental results," IEEE Trans. Ind. Electron., Vol. 60, No. 8, pp. 3025-3033, Aug. 2013.

[62] G.Jayabaskaran, B.Adhavan, and V.Jagannathan, "Torque ripple reduction in permanent magnet synchronous motor driven by field oriented control using iterative learning control with space-vector pulse width modulation," in Proc.ICCCI, 2013.

[63] J. W.Kimbell, P. T. Krein, and Y. Chen, "Hysteresis and delta modulation control of converters using sensorless current mode," IEEE Trans. Power Electron., Vol. 21, No. 4, pp. 1154-1158, Jul. 2006.
[64] B. Singh and V.Rajagopal, "Neural-network-based integrated electronic load controller for isolated asynchronous generators in small hydro generation," IEEE Trans. Ind. Electron., Vol. 58, No. 9, pp. 4264-4274, Sep. 2011.

[65] S. Mikkili and A. K. Panda, "Types-1 and -2 fuzzy logic controllers-based shunt active-filter $\mathrm{I}_{\mathrm{d}}-\mathrm{I}_{\mathrm{q}}$ control strategy with different fuzzy membership functions for power quality improvement using RTDS hardware," IET Power Electron., Vol. 6, No. 4, pp. 818-833, Apr. 2013.

[66] A.M.S. Yunus, A.-A.-S., and M.A.S.Masoum, "Improving dynamic performance of wind energy conversion systems using fuzzy-based hysteresis current-controlled superconducting magnetic energy storage," IET Power Electron., Vol. 5, No. 8, pp. 1305-1314, Sep. 2012.

[67] M. Moghadasian and M. Amiri, "Sensorless speed control of im using adaptive neural-fuzzy inference system," in Proc. AIM, pp. 1028-1033, 2011.

[68] R. Ramchand, K.Gopakumar, C. Patel, K.Sivakumar, A. Das, and H. Abu-Rub, "Online computation of hysteresis boundary for constant switching frequency current-error space-vector-based hysteresis controller for VSI-FED im drives," IEEE Trans. Power Electron., Vol. 27, No. 3, pp. 1521-1529, Mar. 2012.

[69] A. Dey, P.P.Rajeevan, R, Ramchand, K.Mathew, and K.Gopakumar, "A space-vector-based hysteresis current controller for a general n-level inverter-fed drive with nearly constant switching frequency control," IEEE Trans. Ind. Electron., Vol. 60, No. 5, pp. 1989-1998, May 2013.

[70] Z. Song, C. Xia, and Tao Liu, "Predictive current control of three-phase grid-connected converters with constant switching frequency for wind energy systems," IEEE Trans. Ind. Electron., Vol. 60, No. 6, pp. 2451-2464, Jun. 2013.

[71] S.Mishra, G.Malleshan, and P.C.Shekhar, "Biogeography based optimal state feedback controller for frequency regulation of a smart microgird," IEEE Trans. Smart Grid, Vol. 4, No. 1, pp. 628-637, Mar. 2013.

[72] Z. Qi-Jie, Z. Yun, and T. Bin, "A new approach in state feedback controller design of LTI systems with input time delay,"in Proc. CCDC, pp. 2323-2327, 2012.

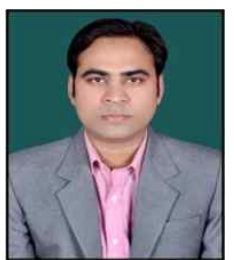

S. P. Gawande received his B.E.and M.Tech degrees in Electrical Engineering from Nagpur University, Nagpur, India, in 1999 and 2009, respectively. $\mathrm{He}$ is currently working towards his Ph.D. degree at the Visvesvaraya National Institute of Technology (VNIT), Nagpur, India.

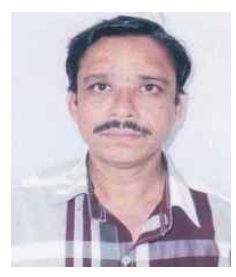

M. R. Ramteke received his M.Tech and $\mathrm{Ph} . \mathrm{D}$. degrees from Nagpur University, Nagpur, India, in 1994 and 2008, respectively. He is currently working as an Associate Professor at the Visvesvaraya National Institute of Technology (VNIT), Nagpur, India. $\mathrm{He}$ has 15 years of experience in the fields of teaching and research. His current research interests include power electronics, resonant converters, FACTS devices and power quality. 